these, those submitted by the Civil Service Commission on the function and organization of the Civil Service Commission and that of the Treasury on recruitment to the Civil Service may be mentioned. Recruitment to the Civil Service is dealt with in memoranda by Prof. W. J. M. Mackenzie, by Mr. B. J. Holloway, by the staff side of the Civil Service National Whitloy Council, and by the Acton Society 'Trust. The last-mentioned is supported by a further memorandum on the attitudes of civic university students towards an administrative career in the Civil Service. This is based on a survey of third-year undergraduate students at the University of Hull, undertaken following a suggestion made in the statement of evidence made to the Committee by the Acton Society Trust. A further memorandum on recruitment to the Civil Service is by the Warden of Nuffield College, Oxford, Mr. D. N. Chester. Another on the same subject by the Business Economists Group is also appended; the Institution of Professional Civil Servants has a memorandum on recruitment to the professional and technical classes; finally, one on the recruitment of gir's to the Civil Service is submitted by Miss Margaret Miles.

\section{Anglo-Romanian Agreement on Co-operation}

A FORMAL agreement on eo-operation has been concluded between the Royal Society and the Academy of the Socialist Republic of Romania with the signature in Bucharest by Academician D. Dumitrescu, First Secretary of the Romanian Academy, and in London by Sir Patrick Linstead, Foreign Secretary of the Royal Society. The agreement makes provision for; (1) the annual exchange of three scientists from each side for lectures and visits to specialized scientific institutions in the other country for periods of fourteen days ; (2) the annual exchange of up to two scientific research workers from each side, for a nine-month period in each case, to study fundamental problems in some aspects of the physical and biological sciences, including their applied aspects. The agreement also calls for the exchange of periodical publications of the two sides and for the encouragement of further such exchanges of publications in specialized branches of the physical and biological seiences between the respective corresponding institutions in the United Kingdom and Romania.

\section{Eleventh Pacific Science Congress}

The eleventh Pacific science congress of the Pacific Seience Association will be held at the University of Tokyo, Japan, during August 22-September 10, 1966, under the auspices of the Science Council of Japan. The inaugural meeting will be held on August 22 and the general meeting on September 3. The first week of the congress will be devoted mainly to symposia, the second to divisional meetings and the third to scientific tours. The organizers are not limiting the number of scientists attending the congress. The branches of science covered by the Pacific Science Association include: meteorology; oceanography; geophysics; geology and soil science; biology; agriculture; forestry; animal science and conservation; fisheries; marine and froshwater sciences; nutrition; public health and medical science; social seiences; anthropology; geography; scientific information and museums. Symposia and divisional meetings will be held on specific topies in these fields. There will also be two congress symposia on $(a)$ population problems in the Pacific, and $(b)$ air and water pollution in the Pacific area, as well as four special symposia with exhibitions and demonstrations on vessels and instruments for oceanic and freshwater research, marine park, primate biology of the Pacific area and tsutsugamushi disease. It is hoped that various meotings of other international scientific organizations will be held in Japan concurrently with the congress.

The Royal Society, as the United Kingdom representative institution in the Pacific Science Association, will be sending an official delegation of ten members to the congress. Members attending other meetings to be held concurrently with the Pacific science congress are invited to become members of the congress, and in addition any qualified scientist may attend the congress and participate in the two weeks of meetings without presenting a paper. Representative institutions havo been requested to accredit all members of the congress to the Organizing Committee, and any United Kingdom scientist planning to attend is asked to inform the Executive Secretary, the Royal Society, Burlington House, London, W.I.

\section{High-pressure Science and Technology}

THE recent international conference on "High Pressures", held at Le Creusot, France, emphasized the important common interests, particularly in engineering and experimental techniques, which link all high-pressure activities. At a special meeting, British delegates felt that better interchange of information between specialized activities would greatly accelerate progress in the United Kingdom. A committee was elected to: (1) organize meetings promoting contacts between specialists in different fields at which informal discussion would be oncouraged; (2) provide a source of information on highpressure activities in Britain, and liaison with American, Continental and other groups; (3) set up an association which all interested in high pressures could join; (4) act as an advisory body to the Government and other authorities. The committee was chosen to represent a variety of interests and will be enlarged as necessary. Members are: K. E. Bett (Imperial College of Science and Technology); C. C. Bradley (National Physical Laboratory); C. H. L. Goodman (Standard Telecommunication. Laboratories, Ltd., Harlow, Acting Chairman); W. R. D. Manning (St. Albans, Herts). All groups in Britain working with high pressures are urged to write to the committee giving a brief outline of their interests. This will enable a provisional directory of high-pressure research to be compiled which will be eirculated to all who write in. It will also form the basis for the association, and for deciding the topics for the first research meetings. Letters should be sent preferably to the acting chairman, but any committee member would be pleased to answer queries.

\section{Scientific Periodicals from the U.S.S.R.}

THE 1966 catalogues of Russian newspapers al:d magazines procurable on a subscription basis through national agencies for Soviet books list several hundred scientific periodicals and more than 250 soctions of the Journal of Abstracts and the Engineering Index, all of which are readily obtainable by Western readers if orders are placed six weeks in advance of publication. An unwelcome feature of these 1966 lists is the rising cost of Russian journals of an academic or technical character, the price of which in most instances has advanced by 18-19 per cent since 1963. Annual charges for volumes of the Journal of Abstracts (Referativnyi Zhurnal) sories have gone up by some 30-40 per eent in the same period. In numerous instances these Russian scientific periodicals, characterized a decade ago by their relative cheapness, are now appreciably more exponsive than their Western counterparts. It is significant that no comparable advances are scheduled in the price of nowspapers, popular magazines and propaganda literature.

\section{Soils of the Mendip District of Somerset}

A RECENT memoir of the Soil Survey of Creat Britain, by D. C. Findlay, gives an account of the soils and landuse of the region between Weston-super-Mare and Bridgwater and extending inland to Shepton Mallet (The Soils of the Mendip District of Somerset. Sheets 279 and 280. Pp. viii $+204+9$ plates. Harpenden: Rothamsted Experimental Station, 1965. 35s.). The area survoyed extends to 279 square miles and includes the Mendip 